Note

\section{Hyperpigment-productive Mutant of Monascus anka for Solid Culture}

\author{
Tadao Hiror, Teiji ShIMA, \\ Tsuneo SuzukI, Mototsugu Tsukioka \\ and Nagahiro OGASAWARA* \\ Niigata Prefectural Institute of Brewing, \\ Niigata, Japan \\ *Department of Agricultural Chemistry, \\ Niigata University, Japan \\ Received June 26, 1978
}

Recently, monascus-pigment is being used as a food coloring additives. It is extracted from solid cultures of the mold with ethanol or propylene glycol.

$\mathrm{Lin}^{1)}$ reported that Monascus sp. F-2, an effective pigment-productive strain in submerged culture, was improve by $N$-methyl- $N^{\prime}$-nitro- $N$-nitrosoguanidine (NTG) treatment, and Su et al. $^{2)}$ reported that red $k o j i$ processing was improved by using an ultraviolet ray-induced mutant of Monascus anka.

However, isolation of a suitable hyperpigmentproductive strain in aerated solid culture with rice or fine flakes of bread has not yet been reported. We have investigated strains belonging to genus Monascus to obtain hyperproductive strains for pigment-production using mechanical koji processing.

Experiments with ultraviolet ray (UV) irradiation followed by NTG treatment were conducted to improve the yield of pigment-production by Monascisis ankka Nakazawa et Sato after screening tests of strains on pigment-production and growth. For conidiation of fungus, the following medium (medium $\mathrm{C}$ ) was used: sucrose $10 \mathrm{~g}, \mathrm{KH}_{2} \mathrm{PO}_{4}, 0.1 \mathrm{~g}, \mathrm{MgSO}_{4} \cdot 7 \mathrm{H}_{2} \mathrm{O} 0.05 \mathrm{~g}$, $\mathrm{NaNO}_{3} 0.2 \mathrm{~g}, \mathrm{KCl} 0.05 \mathrm{~g}, \mathrm{FeSO}_{4} \cdot 7 \mathrm{H}_{2} \mathrm{O} 0.001 \mathrm{~g}$, yeast extract powder $0.3 \mathrm{~g}$, casamino acids $0.5 \mathrm{~g}$, agar $2 \mathrm{~g}$, in $100 \mathrm{ml}$ of distilled water. Conidia of Monascus anka were allowed to from on agar slant with the above medium for 4 days at $30^{\circ} \mathrm{C}$, diluted to about 500 conidia/ $\mathrm{ml}$ with sterile water and irradiated with UV $(100 \mathrm{~V}$, $13 \mathrm{~W}$ ) from a distance of $40 \mathrm{~cm}$ for $2.5 \mathrm{~min}$. On the basis of diameter and pigmentation of the giant colony, three mutants were selected among 98 mutants induced by UV-irradiation. For selecting pigment-productive mutants, the following medium (medium $\mathrm{P}$ ) was used: sucrose $10 \mathrm{~g}$, peptone $1 \mathrm{~g}, \mathrm{KH}_{2} \mathrm{PO}_{4} 0.1 \mathrm{~g}, \mathrm{MgSO}_{4}$. $7 \mathrm{H}_{2} \mathrm{O} 0.05 \mathrm{~g}$, tartaric acid $0.1 \mathrm{~g}$, 1-asparagine $0.3 \mathrm{~g}$, in $100 \mathrm{ml}$ of tap water, and $\mathrm{pH}$ of medium was 4.4. With the selected mutant strain U2, U26 and U55, NTGtreatment was carried out. To $10 \mathrm{ml}$ of conidial suspension of UV mutant, $0.2,0.4$ or $0.6 \mathrm{ml}$ of NTG
Table I. Growth and Pigment-production of Isolated Mutants on Shaking Culture

Each organism was cultured by rotary shaker $(150 \mathrm{rpm})$ at $30^{\circ} \mathrm{C}$ for 8 days.

\begin{tabular}{lccc} 
Organism & $\begin{array}{c}\text { Dry } \\
\text { weight } \\
\text { of } \\
\text { mycelia } \\
(\mathrm{mg} / 200 \mathrm{ml})\end{array}$ & $\begin{array}{c}\text { Pigment } \\
\text { produced } \\
\text { (OD }\end{array}$ & $\begin{array}{c}\text { Pigment- } \\
\text { production } \\
\text { ratio of } \\
\text { mutant to } \\
\text { parent } \\
\text { organism }\end{array}$ \\
\hline M.anka Nakazawa & & & \\
$\quad$ et Sato & 228.2 & 0.088 & 1.00 \\
U2 & 180.3 & 0.353 & 4.01 \\
UN202-6 & 240.4 & 0.201 & 2.28 \\
UN202-12 & 224.9 & 0.463 & 5.26 \\
UN202-13 & 262.8 & 0.629 & 7.15 \\
UN202-14 & 186.5 & 0.379 & 4.32 \\
UN202-15 & 220.3 & 0.256 & 2.91 \\
UN204-6 & 179.0 & 0.402 & 4.57 \\
UN204-8 & 269.7 & 0.382 & 4.34 \\
UN204-9 & 210.0 & 0.403 & 4.58 \\
UN204-15 & 234.0 & 0.470 & 5.34 \\
U55 & 316.5 & 0.503 & 5.72 \\
UN5502-2 & 284.2 & 0.502 & 5.70 \\
UN5502-3 & 281.2 & 0.414 & 4.70 \\
UN5502-8 & 274.8 & 0.532 & 6.05 \\
U26 & 249.3 & 0.612 & 6.95 \\
UN2602-8 & 375.9 & 0.324 & 3.68 \\
UN2602-27 & 248.4 & 0.350 & 3.98 \\
UN2604-4 & 296.4 & 0.644 & 7.32 \\
\hline & & &
\end{tabular}

solution which has a concentration of $1 \mathrm{mg} / \mathrm{ml}$ was added. By these procedures, 18 mutants were selected, and the mutants were allowed to grow in medium $P$ on a rotary shaker for 8 days at $30^{\circ} \mathrm{C}$, and mycelium yield and pigment-production were measured. As shown in Table I, pigment-productivity of each of these mutants, which was measured by absorbancy at $500 \mathrm{~nm}$, was improved in comparison with parent organisms as follows: 7.32, 7.15 and 6.05 times for UN2604-4, UN202-13 and UN5502-8, respectively.

To examine the pigment-production of mutants on rice $k o j i$, seven mutants and the original strain were incubated on steamed rice in Erlenmeyer flasks for 8 days at $34^{\circ} \mathrm{C}$. The preparation of rice medium for solid culture was follows: hulled rice of $72 \%$ grade was soaked in aqueous solution, which was adjusted to $\mathrm{pH} 2.0$ with lactic acid, for $15 \mathrm{hr}$ at $10^{\circ} \mathrm{C}$. After the solution was removed, the soaked hulled rice was autoclaved for $15 \mathrm{~min}$ at $120^{\circ} \mathrm{C}$ and cooled to room temperature. As shown in Table II, two mutants, strain UN2604-4 and UN202-13, showed hyperpigment-production, when the absorbancy of their ethanolextracts were measured at $500 \mathrm{~nm}$. The former was 17.7 times and the latter 21.4 times greater, respectively, in comparison with the parent organism.

Some differences in thermostability of conidia and 
Table II. Pigment-production of Isolated Mutants on Solid Culture with Steamed Hulled Rice

Each organism was cultured in $500 \mathrm{ml}$ Erlenmeyer flask containing $20 \mathrm{~g}$ of steamed hulled rice at $34^{\circ} \mathrm{C}$ for 8 days.

\begin{tabular}{lrc} 
Organism & $\begin{array}{c}\text { Pigment } \\
\text { in } \\
\text { rice } k \text { oji } \\
\text { (OD } 500 \mathrm{~nm} \text { ) }\end{array}$ & $\begin{array}{c}\text { Pigment-produc- } \\
\text { tion ratio of } \\
\text { mutant to parent } \\
\text { organism }\end{array}$ \\
\hline $\begin{array}{l}\text { M.anka Naka- } \\
\text { zawa } \text { et } \text { Sato }\end{array}$ & 31.1 & 1.0 \\
U2 & 398.0 & 12.8 \\
UN202-13 & 666.0 & 21.4 \\
UN202-14 & 450.0 & 14.5 \\
U55 & 544.0 & 17.5 \\
UN5502-8 & 464.0 & 14.7 \\
U26 & 492.0 & 15.8 \\
UN2604-4 & 552.0 & 17.7 \\
\hline
\end{tabular}

ascospores between mutant UN202-13 and the parent organism were observed, Conidia and ascospores of the parent organism died at $65^{\circ} \mathrm{C}$ and $70^{\circ} \mathrm{C}$, respectively, whereas those of mutant UN202-13 died at $55^{\circ} \mathrm{C}$ and $60^{\circ} \mathrm{C}$, respectively. The results indicated that mutant UN202-13 has slightly lower thermostability in comparison with that of the parent organism.

For comparisons of conidia and ascospores in pigment-productivity, mutant UN202-13 was cultured on agar slants with two media, that is, medium $C$ and medium $P$ for obtaining conidia and ascospores, respec- tively. To obtain conidia, conidial suspension prepared from organisms grown on medium $\mathrm{C}$, was filtered through absorbent cotton to separate mycelia. Isolation of ascospore was performed by heating the suspension, which was prepared from organisms grown on medium $\mathrm{P}$, for 20 min at $55^{\circ} \mathrm{C}$ to kill conidia. The serial transfers with each medium were made 10 times by using the conidia and ascospores obtained, then the giant colonies were cultured for 10 days at $30^{\circ} \mathrm{C}$ with each strain of conidial and ascospore origin. Both giant colonies macroscopically showed the same growth rate and pigmentation characteristics. The properties of mutant UN202-13, which were derived from conidium with UV irradiation followed by NTG treatment, appeared to be inherited by the ascospore.

From these results, we decided to use mutant UN20213 for large scale production of monascus-pigment by solid culture with aeration using rice or fine flakes of bread.

Acknowledgments. The authors wish to express their sincere thanks to Mr. Shunzo Takizawa who helped directly in this work and the Akaisake Institution, Kanemasu Shuzo Co. and Toyo Create Co. for providing the facilities.

\section{REFERENCES}

1) C. F. Lin, J. Ferment. Technol., 51, 407 (1973).

2) Y. C. Su, W. L. Chen, H. C. Wong and W. H. Wang, $J$. Chinese Chem. Soc., 8, 46 (1970). 